\title{
NOTICE IN RULE 23(b)(2) CLASS ACTIONS FOR MONETARY RELIEF: JOHNSON v. GENERAL MOTORS CORP.
}

Class actions brought under rule 23 of the Federal Rules of Civil Procedure ${ }^{1}$ have proven to be valuable in enforcing many

1 Because of the interrelationships of the various parts of rule 23 , entitled "Class Actions," all parts of the rule pertinent to this Comment are here reproduced for the reader's convenience.

(a) Prerequisites to a Class Action. One or more members of a class may sue or be sued as representative parties on behalf of all only if (1) the class is so numerous that joinder of all members is impracticable, (2) there are questions of law or fact common to the class, (3) the claims or defenses of the representative parties are typical of the claims or defenses of the class, and (4) the representative parties will fairly and adequately protect the interests of the class.

(b) Class Actions Maintainable. An action may be maintained as a class action if the prerequisites of subdivision (a) are satisfied, and in addition:

(2) the party opposing the class has acted or refused to act on grounds generally applicable to the class, thereby making appropriate final injunctive relief or corresponding declaratory relief with respect to the class as a whole; or

(3) the court finds that the questions of law or fact common to the members of the class predominate over any questions affecting only individual members, and that a class action is superior to other available methods for the fair and efficient adjudication of the controversy. The matters pertinent to the findings include: (A) the interest of members of the class in individually controlling the prosecution or defense of separate actions; (B) the extent and nature of any litigation concerning the controversy already commenced by or against members of the class; (C) the desirability or undesirability of concentrating the litigation of the claims in the particular forum; (D) the difficulties likely to be encountered in the management of a class action.

(c) Determination by Order Whether Class Action to be Maintained; Notice; Judgment; Actions Conducted Partially as Class Actions.

(1) As soon as practicable after the commencement of an action brought as a class action, the court shall determine by order whether it is to be so maintained. An order under this subdivision may be conditional, and may be altered or amended before the decision on the merits.

(2) In any class action maintained under subdivision (b) (3), the court shall direct to the members of the class the best notice practicable under the circumstances, including individual notice to all members who can be identified through reasonable effort. The notice shall advise each member that (A) the court will exclude him from the class if he so requests by a specified date; (B) the judgment, whether favorable or not, will include all members who do not request exclusion; and (C) any member who does not request exclusion may, if he desires, enter an appearance through his counsel. 
private rights and public policies. ${ }^{2}$ Givil rights plaintiffs, in particular, have found the $23(\mathrm{~b})(2)$ class action especially attractive. ${ }^{3}$ Many (b)(2) class action plaintiffs have won monetary awards such as back pay in title VII employment discrimination suits, ${ }^{4}$ as

(3) The judgment in an action maintained as a class action under subdivision (b) (1) or (b) (2), whether or not favorable to the class, shall include and describe those whom the court finds to be members of the class. The judgment in an action maintained as a class action under subdivision (b) (3), whether or not favorable to the class, shall include and specify or describe those to whom the notice provided in subdivision (c) (2) was directed, and who have not requested exclusion, and whom the court finds to be members of the class.

(4) When appropriate (A) an action may be brought or maintained as a class action with respect to particular issues, or (B) a class may be divided into subclasses and each subclass treated as a class, and the provisions of the rule shall then be constured and applied accordingly.

(d) Orders in Conduct of Actions. In the conduct of actions to which this rule applies, the court may make appropriate orders: (1) determining the course of proceedings or prescribing measures to prevent undue repetition or complication in the presentation of evidence or argument; (2) requiring, for the protection of the members of the class or otherwise for the fair conduct of the action, that notice be given in such manner as the court may direct to some or all of the members of any step in the action, or of the proposed extent of the judgment, or of the opportunity of members to signify whether they consider the representation fair and adequate, to intervene and present claims of defense, or otherwise to come into the action; (3) imposing conditions on the representative parties or on intervenors; (4) requiring that the pleadings be amended to eliminate therefrom allegations as to representation of absent persons, and that the action proceed accordingly; (5) dealing with similar procedural matters. The orders may be combined with an order under Rule 16, and may be altered or amended as may be desirable from time to time.

(e) Dismissal or Compromise. A class action shall not be dismissed or compromised without the approval of the court, and notice of the proposed dismissal or compromise shall be given to all members of the class in such manner as the court directs.

Fed. R. Crv. P. 23.

2 "To consumer advocates, environmentalists, civil libertarians, and others who would reform society through the courts, Rule 23 became a new charter. For those who simply sought to enforce the laws as written, the new Rule provided means by which large wrongs could be rectified though they caused individually small (but collectively massive) injuries." Dam, Class Action Notice: Who Needs It?, 1974 Sup. Cr. Rev. 97. See also Chayes, The Role of the Judge in Public Law Litigation, 89 HARv. L. REv. 1281 (1976). For a discussion of the applicability of class actions to various areas of substantive law, see generally $3 \mathrm{~B}$ MOORE's Federax Practice If 23.02 (2d ed. 1978).

3 In 1978, civil rights class actions $(1,477)$ accounted for $57.1 \%$ of the total 2,586 class actions filed in United States district courts. The balance of class actions was divided almost equally among prisoner petitions, antitrust suits, and securities, commodities, exchange and other statutory actions. See [1978] AD. OfF. United States Courts Dir. AnN. Rep. 226-27. Over half of the civil rights class actions were job related. Id. 554. Most of those employment discrimination cases were probably brought under rule 23(b)(2). See W. Connolxy, A Practicar GUDE to Equal EMPlotanent OpPortuntTy 511 (1975).

4 See note 12 infra. 
well as the usual equitable relief available under (b)(2), while avoiding the often onerous procedures governing class actions for damages under rule $23(\mathrm{~b})(3) .^{5}$ Most significantly, (b)(2) plaintiffs do not face a mandatory obligation to provide individual notice to all identifiable members of the class. $^{6}$ As a result, civil rights plaintiffs have often been free from one of the major costs of class action litigation that can hinder or deter private enforcement of public policies.?

The Fifth Circuit opinion in Johnson $v$. General Motors Corp. ${ }^{8}$ may signal an end to the advantages of (b)(2) class actions. The court ruled that individual notice to all class members is constitutionally required in order to bind the class by the result of a (b)(2) class action seeking injunctive and monetary relief under title VII. ${ }^{9}$ Significantly the Fifth Circuit implicitly overruled two previous decisions to reach this result. ${ }^{10}$ The decision may portend more difficult times for employment discrimination suits in the Fifth Circuit. ${ }^{11}$

This Comment is critical of Johnson. It argues that the Fifth Circuit unnecessarily implicated constitutional issues and adjudicated those issues incorrectly. It concludes that notice is not

5 See FED. R. Civ. P. 23(b)(2), (b)(3), (c)(2), \& (c)(3), note 1 supra. For examples of cases that have benefitted from the less stringent (b) (2) requirements, see Kelly v. General Motors Corp., 425 F. Supp. 13 (E.D. Pa. 1977); St. Marie v. Eastern R.R. Ass'n, 72 F.R.D. 443, 450 n.2 (S.D.N.Y. 1976).

6 FED. R. Crv. P. 23(b)(2), note 1 supra. Individual notice for all identifiable class members is required in (b) (3) class actions regardless of cost. Eisen v. Carlisle \& Jacquelin, 417 U.S. 156 (1974). "[E]xcept in the most extraordinary circumstances, the plaintiff must always bear the initial cost of giving notice." Manual for Complex Litigation $\$ 1.45$, reprinted in 5 Ccass Action REP. 134, 163 (1978) (footnotes omitted). See note 52 infra \& accompanying text.

7 See, e.g., Considine v. Park Nat'l Bank, 64 F.R.D. 646 (E.D. Tenn. 1974) (class certification denied in part because of prohibitive costs of notice); P.D.Q. Inc. v. Nissan Motor Corp., 61 F.R.D. 372 (S.D. Fla. 1973) (court tailored class size to accommodate plaintiff's limited resources); Ralston v. Volkswagenwerk, A.G., 61 F.R.D. 427 (W.D. Mo. 1973) (class allegations dismissed in part because named plaintiff lacked funds); Notice Costs, 5 CLAss Action Rep. 2 (1978). See also Dam, supra note 2, at 97-99; Note, Managing the Large Class Action: Eisen v. Carlisle \& Jacquelin, 87 Harv. L. Rev. 426 (1973). But cf. Note, The Rule 23(b)(3) Class Action: An Empirical Study, 62 Geo. L.J. 1123, 1145-48 (1974) (costs of notice in sample of class actions found to be insubstantial).

8598 F.2d 432 (5th Cir. 1979), reh. denied, 605 F.2d 554 (1979).

9 Id. 437.

10 In two employment discrimination class actions under (b)(2) which sought monetary relief, notice was not required by the Fifth Circuit. Bolton v. Murray Envelope Corp., 553 F.2d 881 (5th Cir. 1977); Robinson v. Union Carbide Corp., 544 F.2d 1258 ( 5 th Cir.), cert. denied, 434 U.S. 822 (1977). The discussion in these cases pertaining to the immediate issues was, unfortunately, minimal.

11 See notes 21-23 infra \& accompanying text. 
constitutionally required in all (b)(2) class actions seeking monetary as well as injunctive or declaratory relief. Requiring class representatives to give other class members notice in (b)(2) actions is a matter of discretion for the trial judge, to be exercised to ensure adequate representation of all class members without unduly burdening prosecution of the class action. The Comment also notes considerations which should inform the court's decision of whether to require notice in a particular case.

\section{Johnson v. General Motors Corp. AND ITs IMPACT upon Giass Action Litigation}

\section{A. The Johnson Case}

Herman Johnson, a black employee at a General Motors plant in Atlanta, Georgia, used 23(b)(2) as a vehicle to charge his employer with discriminatory employment practices under title VII ${ }^{12}$ and 42 U.S.C. $\$ 1981 .{ }^{13}$ His complaint sought both injunctive and monetary (back pay) relief. ${ }^{14}$ The district court dismissed Johnson's complaint, ${ }^{15}$ holding that he was barred by the res judicata effect of a prior class action, Rowe $v$. General Motors Corp., ${ }^{16}$ involving racial discrimination at the same plant. Johnson had been a member of the class in Rowe, but had never been given notice of the suit. The class representatives in Rowe prevailed on the issue of discrimination and won an injunction. Although the three class representatives received individual settlements of $\$ 1,000$ each, they never sought classwide monetary relief. ${ }^{17}$

On appeal, ${ }^{18}$ the court ruled that Johnson's claim for injunctive relief was barred by Rowe: "[A]n absent class member is bound by the res judicata effect of a [prior] (b)(2) class action to the extent that the judgment concerns injunctive or declaratory

1242 U.S.C. $\$ 2000 \mathrm{e}-2$ (1976). Title VII prohibits employment discrimination based on race, sex, national origin, or religion, and provides for injunctive relief, reinstatement, and hiring, with or without back pay to remedy discriminatory employment practices. Id. $\$ 2000 \mathrm{e}-5(5)(\mathrm{g})$.

1342 U.S.C. $\$ 1981$ gives to all persons in the United States "the same right ... to make and enforce contracts, to sue, be parties, give evidence, and to the full and equal benefit of all laws and proceedings for the security of persons and property as is enjoyed by white citizens."

14 Johnson v. General Motors Corp., 598 F.2d 432, 433-34 (5th Cir. 1979).

15 Id. 434.

164 Empl. Prac. Dec. \7715 (N.D. Ga. 1969), rev'd and remanded, 457 F.2d

348 (5th Cir. 1972).

$17598 \mathrm{~F} .2 \mathrm{~d}$ at 434 .

18 Id. 432. 
relief, even when no notice was provided." 19 Johnson's claim to monetary relief, however, could not be barred by Rowe: "Before an absent class member may be forever barred from pursuing an individual damage claim ... due process requires that he receive some form of notice that the class action is pending and that his damage claims may be adjudicated as part of it." 20

\section{B. The Probable Impact of Johnson}

Although the Fifth Circuit was concerned with protecting the rights of absent class members, the court has provided defendants in $23(\mathrm{~b})(2)$ class actions with a very useful procedural device to combat the prosecution of the claims against them. At the initiation of a (b)(2) class action for monetary relief the defendant could request that the court order that notice be sent to all class members. The defendant would argue that failure to send notice and thereby bind all class members by the judgment would be unfair and a waste of judicial resources; ${ }^{21}$ absent a binding effect on all class members, the action would be pointless. Although killing the class action would likely be the primary motivation behind the request, ${ }^{22}$ the absolute terms with which the holding in John-

19 Id. 438. Johnson had suggested four deficiencies in the Rowe litigation which, he argued, should have released him from any res judicata effect: (I) The court in Rowe failed to certify formally the case as a class action as required by rule $23(\mathrm{c})(1)$; (2) the Rowe court failed to define formally the class and its members as required by rule $23(\mathrm{c})(3)$; (3) the court did not order notice for absent class members; and (4) the class interests had not been adequately represented. Id. 434. The first and second of these alleged deficiencies were rejected by the court. Id. 434-35. The fourth alleged deficiency was not reached by the court. Id. 438. The third deficiency was accepted and is the subject of this Comment.

$20 \mathrm{Id}$.

21 To the extent that the doctrine of mutuality of estoppel is still recognized in federal courts, absent class members may have a strong interest in receiving notice, particularly so as to be able to participate in the judgment. In Schrader v. Selective Serv. Sys. Local Bd. No. 76, 470 F.2d 73, 75 (7th Cir.), cert. denied, 409 U.S. 1085 (1972), absent members were not permitted to enforce a class action judgment in their favor because, due to the lack of notice, had the class lost the suit the absent members would not have been bound. But, as the Seventh Circuit noted in Jimenez v. Weinberger, 523 F.2d 689, 700 n.25 (7th Cir. 1975), cert. denied, 427 U.S. 912 (1976), the Schrader view is suspect because it depends on a doctrine which is dying in the federal courts. See Blonder-Tongue Laboratories, Inc. v. University of Ill. Foundation, 402 U.S. 313 (1971); IB MoorE's FEderaI Practice ff 0.4.2[1] n.12 (Cum. Supp. 1979-80); Restatement (Second) of JuDGMents $\$ 88$, Reporter's Note ('Tent. Draft No. 3, 1976).

22 Notice will give defendant little additional protection against subsequent claims by absent members. Because the absent class members would be asserting substantially identical claims, "the doctrine of stare decisis would apply in an uncommonly powerful way.” Dam, supra note 2, at 120. Professor Dam also notes:

Defendants will not normally place much value on binding class members.

If a defendant loses, the merger effect of res judicata is usually irrelevant.

As for barring further actions by class members, it would be the rare class 
son is stated, and the constitutional grounds upon which it is based, indicate that the request would probably be granted. Were that result to occur, many (b)(2) actions would then be dropped, or at least the prayer for monetary damages would be discontinued, because of the inability or unwillingness of the class representatives to pay for the notice. ${ }^{23}$ In some cases the notice requirement may compel the judge to deny class certification either because class members are impossible to identify and locate, ${ }^{24}$ or because the costs of notice could be prohibitive when compared to the potential recovery. ${ }^{25}$

In order to avoid the costs of notice, the class representatives could request that notice be postponed until after the liability stage of the trial. Class actions are often tried in a two-step, "bifurcated" process. ${ }^{26}$ The first stage involves determination of

member who would attempt to tread the same ground as the unsuccessful representative plaintiff. To the extent that class actions are the result of a lawyer's entrepreneurship, second actions need hardly be feared, for what entrepreneur would invest time and money in a venture already demonstrated to be profitless?

Id. Accord, 37 Oнпо Sт. L.J. 386, 405 (1976). See also Wetzel v. Liberty Mut. Ins. Co., 508 F.2d 239, 256 (3d Cir.), cert. denied, 421 U.S. 1011 (1975) (cohesiveness of $(b)(2)$ class triggers stare decisis effect). Cf. Philadelphia Elec. Co. v. Anaconda Am. Brass Co., 43 F.R.D. 452, 459 (E.D. Pa. 1968) (warning against the exaggeration of the "specter of an occasional successful collateral attack on the basis of due process" where notice is inadequate); Cartt v. Superior Court, 50 Cal. App. 3d 190, 124 Cal. Rptr. 376 (1975) (suggesting that a distinction be drawn between notice required to proceed with the action and notice required to apply res judicata in subsequent suit). Also, if the facts change substantially after the first suit, defendant would have to relitigate the matter as a new action. See Restatement (Second) of Judgments \$68.1, Comment b (Tent. Draft No. 4, 1977); id., Reporter's Note, at 44; 2 Newberg on Class Actrons $\$ 2752$ (1977).

23 The class representatives must usually bear the cost of notice. See notes 6-7 supra and note 27 infra \& accompanying text.

24 See Inmates of Milwaukee County Jail v. Petersen, 51 F.R.D. 540, 542 (E.D. Wis. 1971). The court took judicial notice of the high turnover and transiency of detained persons in the county jail. The denial of class certification was based in part on the conclusion that "the effort which would be required to give reasonable notice to those persons who would be affected by the judgment, were this a class action, would create more problems than it would solve." Id. 542 .

25 See Considine v. Park Nat'l Bank, 64 F.R.D. 646 (E.D. Tenn. 1974). The plaintiff contended that a class in excess of 10,000 members was entitled to recover interest paid in excess of the usurious rate. The applicable statute limited recovery to twice the amount of interest paid. One reason for denial of class certification was that the cost of identifying and notifying class members "could be economically prohibitive when compared to the potential recovery." Id. 648 .

26 See, e.g., International Bhd. of Teamsters v. United States, 431 U.S. 324, 360-62 (1977); Robinson v. Union Carbide Corp., 544 F.2d 1258, 1260 (5th Cir.), cert. denied, 434 U.S. 822 (1977); Baxter v. Savannah Sugar Ref. Corp., 495 F.2d 437, 443-14 (5th Cir.), cert. denied, 419 U.S. 1033 (1974). The authority for this practice may be derived from Federal Rule of Civil Procedure 12(b) which in relevant part provides: "[t]he court . . . may order a separate trial on any separate issue." 
liability and, if appropriate, class-wide injunctive relief. The second stage determines the appropriateness and calculation of individualized or class-wide monetary damages. If plaintiffs win on the question of liability, the defendant may then be ordered to pay the costs of notice.27 Support for this procedure may be found in the Johnson opinion. ${ }^{28}$

A defendant, however, could successfully resist postponement of notice. If notice is delayed until after the liability stage, it is clear that it will never be given in those cases where the defendant wins on the issue of liability. But if the holding in Johnson is given its fullest force, unnotified absent class members with monetary claims would not be bound by res judicata and could force the defendant to relitigate the same issues. The court would likely agree that this is inefficient and unfair to the defendant. ${ }^{29}$

Alternatively, the class representatives could attempt to limit Johnson to its facts, producing an interpretation that due process requires notice to absent class members only if the defendant's liability has already been proven. Absent, unnotified class members would then be bound by a verdict for the defendant on the liability issue and the defendant would have no objection to postponing the issuance of notice. However, it seems that if the John-

27 The Supreme Court has made clear that the costs of identification and notice in a (b) (3) class action must usually be borne by the plaintiff. See Oppenheimer Fund, Inc. v. Sanders, 437 U.S. 340, 356-59 (1978); Eisen v. Carlisle \& Jacquelin, 417 U.S. 156, 178-79 (1974). See also Comment, Cost of Notice in Class Actions After Oppenheimer Fund, Inc. v. Sanders, 78 Corum. L. Rev. 1517 (1978). There is no apparent reason why the rule should be any different for notice ordered at the outset of a (b) (2) action. Most courts have imposed notice costs in (b) (2) actions on the plaintiffs. 4 NEWBERG ON CLASS Actrons $\$ 7992 \mathrm{~g}$, n.127 (Supp. 1978). However, as was held in Meadows v. Ford Motor Co., 62 F.R.D. 98, 102 (W.D. Ky. 1973), aff'd as modified on other grounds, 510 F.2d 939 (6th Cir. 1975), cert. denied, 425 U.S. 998 (1976), when notice is given after the defendant has been found liable, the cost should be borne by the defendant. Such orders would not be prohibited by Oppenheimer because that case dealt only with costshifting during the discovery phase of litigation, 437 U.S. at 356-59, and is therefore distinguishable from a case in which liability has already been established. The objection to cost shifting in Eisen was that it was based on a preliminary hearing on the merits which was not authorized by the rule and was possibly prejudicial to the defendant. 417 U.S. at 178-79. This objection does not apply when liability has been determined during an initial stage of the trial itself.

28 "In some cases it may be proper to delay notice until a more advanced stage of the litigation; for example, until after class-wide liability is proven." 598 F.2d at 438 .

29 Cf. Women's Comm. for Equal Employment Opportunity v. National Broadcasting Co., 71 F.R.D. 666, 671 (S.D.N.Y. 1976) (notice ordered in pre-liability stage of (b) (2) class action for injunctive and monetary relief); Burwell v. Eastern Airlines, Inc., 68 F.R.D. 495, 499 (E.D. Va. 1975) (At pre-liability stage, and in consideration of res judicata effect of a judgment in a (b) (2) class action, "[a]cting upon the principal [sic] that every person to be bound by a judgment is entitled to representation of their own choosing, this Court, in its discretion, will require that notice be given."). 
son court had intended to so severely limit its holding, it would have made that clear, or at least qualified the language of its holding. The court did neither. Johnson will be analyzed here in terms of its literal holding that notice is constitutionally required in all class actions seeking monetary relief. Other courts have previously indicated support for this position, ${ }^{30}$ and yet other courts will likely be urged to adopt it in the future.

\section{The Unnecessary Consideration of CONSTITUTIONAL ISSUES}

The Johnson court reached the issue of notice in (b)(2) class actions seeking monetary relief only after it implicitly resolved two initial issues: ( 1 ) whether or not monetary relief can be granted in (b)(2) class actions and (2) whether or not notice is constitutionally required in all class actions. These controversial issues have yet to be settled authoritatively by the Supreme Court. A clear majority position on each issue, however, has emerged in the lower federal courts: monetary relief can be granted in (b)(2) actions, ${ }^{31}$ and notice is not constitutionally required in all class

30 See Ives v. W.T. Grant Co., 522 F.2d 749, 764 (2d Cir. 1975) (The court stated with approval, "Plaintiffs had asked for an injunction ordering Grant's to return money allegedly collected unlawfully. This was refused on the grounds that such an award would in actuality be class-wide damages and thus unavailable without proper notice."); Fertig v. Blue Cross, 68 F.R.D. 53, 59 (N.D. Iowa 1974) (Although notice is not generally mandatory in a $(\mathrm{b})(2)$ action, where $\$ 500,000,000$ in damages is sought, "serious constitutional issues would be raised . . . unless notice at least equal to that required by $23(\mathrm{c})(3)$ was ordered by the court under 23(d)(2)." ); Ellison v. Rock Hill Printing \& Finishing Co., 64 F.R.D. 415, 417 (D.S.C. 1974).

31 Although (b)(2) speaks only of "final injunctive relief or corresponding declaratory relief," most courts which have considered the question have permitted monetary relief to be sought in a (b) (2) class action. This position has been adopted by the Third, Fourth, Fifth, Sixth, Seventh and Eighth Circuits. 4 Newberg on Class Actions $\$ 7989$ (1977). Two different rationales have been used to reach this result. One line of cases takes the position that the money awarded is an integral part of the equitable relief that is granted. See, e.g., Robinson v. Lorillard Corp., 444 F.2d 791, 802 (4th Cir.), cert. dismissed, 404 U.S. 1006 (1971); Rhodes v. Weinberger, 66 F.R.D. 601, 604 (E.D. Pa. 1975). This approach may be rooted in the "clean-up" doctrine of the courts of equity or in the policies of title VII which are so often enforced through (b)(2) actions. See 37 Orno ST. L.J. 386, 395 (1976). The major criticism of this rationale is that rule $23(\mathrm{~b})(2)$ specifically speaks of "injunctive" or "declaratory" relief, which arguably excludes broader forms of equitable relief. See Note, Antidiscrimination Class Actions Under the Federal Rules of Civil Procedure: The Transformation of Rule 23(b)(2), 88 YALE L.J. 868, 878 (1979) [hereinafter cited as Antidiscrimination class Actions].

The other rationale for allowing monetary awards in (b) (2) actions is based upon the Advisory Committee note to rule $23(\mathrm{~b})(2)$ : "The subdivision does not extend to cases in which the appropriate final relief relates exclusively or predominanily to money damages." Proposed Amendments to Rules of Civil Procedure for the United States District Courts, Advisory Committee Notes, 39 F.R.D. 73, 102 
actions. $^{32}$.The issue in Johnson would never have arisen if the court had not accepted these majority positions. For if monetary relief can be sought and granted only under subdivision (b)(3), then failure to provide notice, as required in all (b)(3) actions pursuant to subdivision (c)(2), precludes the res judicata effect of the earlier suit. ${ }^{33}$ Similarly, if notice is constitutionally required in

(1966) (emphasis added) [hereinafter cited as Advisory Comm. Note]. These words have been taken as meaning that monetary relief may be awarded as long as it does not predominate over the requested injunctive and declaratory relief. See, e.g., Bing v. Roadway Express, Inc., 485 F.2d 441, 448 (5th Cir. 1973); Lynch v. Sperry Rand Corp., 62 F.R.D. 78, 85 (S.D.N.Y. 1973). The problem with this approach is that "predominant" is almost meaningless. Cf. Wetzel v. Liberty Mut. Ins. Co., 508 F.2d 239 (3d Cir.), cert. denied, 421 U.S. 1011 (1975) (monetary relief may still be awarded although issue of injunction is moot); Rhodes v. Weinberger, 66 F.R.D. 601, 604 (E.D. Pa. 1975) ("The crux is not the type of relief sought but whether the alleged conduct of the party opposing the class is such that injunctive relief is appropriate.").

Both of these positions have been criticized by commentators who believe that rule 23(b) was structured to create mutually exclusive categories of class actions based on the form of relief sought. See, e.g., Antidiscrimination Class Actions, supra; Barnard, Title VII Class Actions: The "Recovery Stage," 16 WM. \& MARY L. Rev. 507, 519-27 (1975); Edwards, The Back Pay Remedy in Title VII Class Actions: Problems of Procedure, 8 GA. L. REv. 781, 797-803 (1974).

32 See, e.g., Alexander v. Aero Lodge No. 735, 565 F.2d 1364, 1374 (6th Cir. 1977); Bolton v. Murray Envelope Corp., 553 F.2d 881, 883 (5th Cir. 1977); Larionoff v. United States, 533 F.2d 1167, 1186 (D.C. Cir. 1976), aff'd, 431 U.S. 864 (1977); Frost v. Weinberger, 515 F.2d 57, 65 (2d Cir.), cert. denied, 424 U.S. 958 (1976); Wetzel v. Liberty Mut. Ins. Co., 508 F.2d 239 (3d Cir.), cert. denied, 421 U.S. 1011 (1975); Northern Natural Gas Co. v. Grounds, 292 F. Supp. 619 (D. Kan. 1968), aff'd in part, 441 F.2d 704 (10th Cir.), cert. denied, 404 U.S. 951 (1971). Cf. Sosna v. Iowa, 419 U.S. 393, 397 n.4 (1975) ((b)(2) class actions not seeking monetary relief may not raise constitutional issues).

Commentators have been nearly unanimous in their support of this view. See, e.g., Miller, Problems of Giving Notice in Class Actions, 58 F.R.D. 313, 313-17 (1973); 3B Moore's Federal Practice fif 23.55, 23.72 (2d ed. 1978); 2 Newberg on Class Actions $\$ 2550 a$ (1977); 7A C. Wright \& A. Mnlem, Federal Practice and Procedure: CIVI $\$ 1786$ (1972); Note, Collateral Attack on the Binding Effect of Class Action Judgments, 87 Harv. L. Rev. 589, 605 (1974) [hereinafter cited as Collateral Attack]; Comment, The Importance of Being Adequate: Due Process Requirements in Class Actions Under Federal Rule 23, 123 U. PA. L. REV. 1217, 1233 (1975) [hereinafter cited as Being Adequate]; Comment, Adequate Representation, Notice and the New Class Action Rule: Effectuating Remedies Provided by the Securities Laws, 116 U. PA. L. REv. 889 (1968) [hereinafter cited as Adequate Representation]. But see Comment, Can Due Process Be Satisfied by Discretionary Notice in Federal Class Actions?, 4 Creighton I. Rev. 268 (1971). For a discussion of the rationale used in some of these cases and comments see notes 65-76 infra \& accompanying text.

At one time the Second Circuit held that due process required notice in all class actions, Eisen v. Carlisle \& Jacquelin, 391 F.2d 555, 564 (2d Cir. 1968), subsequent appeal on other grounds, 417 U.S. 156 (1974), but has since changed its view. See Ives v. W.T. Grant Co., 522 F.2d 749 ( $2 \mathrm{~d}$ Cir. 1975). Another decision requiring notice in all class actions, Schrader v. Selective Serv. Sys. Local Bd. No. 76, 470 F.2d 73 (7th Cir.), cert. denied, 409 U.S. 1085 (1972), has come under increasing attack within its own circuit. See Jiminez v. Weinberger, 523 F.2d 689,700 n.25 (7th Cir. 1975); Bijeol v. Benson, 513 F.2d 965, 968 n.3 (7th Cir. 1975); Hopson v. Schilling, 418 F. Supp. 1223, 1241 n.22 (N.D. Ind. 1976).

33 See FED. R. Crv. P. 23(c)(3), supra note 1. 
all class actions, then the lack of notice in the earlier class action precludes any res judicata effect of the earlier suit upon later claims, whether injunctive or monetary.

Because the Fifth Circuit, prior to Johnson, had adopted the majority position on these two issues, the Johnson court felt constrained to hold that notice is constitutionally required in (b)(2) class actions for monetary relief. This was both an unnecessary and unfortunate result. It is a highly regarded principle that courts should not reach constitutional issues if a case can be decided on other grounds. ${ }^{34}$ This maxim has potent application to treatment of the Federal Rules of Civil Procedure, which carry a strong presumption of validity. ${ }^{35}$ As written, the rules do not require notice in a (b)(2) class action, yet they bind all class members by the result; ${ }^{36}$ Johnson is tantamount to invalidation of these rules. The Johnson court based its opinion on due process when it could have produced the same result-authorization for Johnson to proceed with his claim-without reaching any constitutional issues. Two such avenues were open to the court.

First, the court could have held that Rowe had not been a valid class suit. ${ }^{37}$ In Rowe, the district court had neglected to formally certify the case as a class action..$^{38}$ On appeal, the Fifth Circuit, in effect, retroactively certified that proceeding as a class action. $^{39}$ Although there was precedent in the circuit for doing this under special circumstances, ${ }^{40}$ the wisdom of this procedure was questioned by Judge Fay in his special concurrence in Johnson: "As a matter of fact, Rowe was only a class action because we said it was!" 41 Such a use of judicial fiat must be seriously questioned,

${ }^{34}$ See, e.g., Califano v. Yamasaki, 442 U.S. 682, 692-93 (1979); Brown v. Allen, 344 U.S. 443, 540 (1953) (Jackson, J., concurring).

35 "[T] There is a strong presumption that the Rule qua rule is valid." $3 B$

Moore's Fenerax Practice $\llbracket 23-441$ (2d ed. 1978). See also id. $\llbracket 23.02[5]$.

36 See FED. R. Grv. P. 23(c)(3), supra note 1.

37 This issue was raised on appeal by Johnson. See note 18 supra.

38 Rowe v. General Motors Corp., 4 Emp. Prac. Dec. I 7715 (N.D. Ga. 1969), rev'd and remanded, 457 F.2d 348 (5th Cir. 1972).

39 Rowe v. General Motors Corp., 457 F.2d 348, 359 (5th Cir. 1972).

40 Bing v. Roadway Express, Inc., 485 F.2d 441 (5th Cir. 1973).

41 Johnson v. General Motors Corp., 598 F.2d 432, 439 (5th Cir. 1979). Judge Fay also noted "some of the problems [for Johnson's suit] created by our failure to adhere to those procedures outlined in Rule 23. This should serve as a "cautionary signal' to all of us." Id.

The Johnson court explicitly relied on Bing v. Roadway Express, Inc., 485 F.2d 441 (5th Cir. 1973), to uphold the validity of the uncertified procedure. 598 F.2d at 435 . Bing held that, notwithstanding a failure to certify the class as required by rule 23, a class action may still proceed. Bing is, however, distinguishable from Johnson on two grounds. First, the court in Bing could "infer from the record's silence that all parties to the action knew of its class nature and acquiesced in it." 
especially when it unnecessarily implicates the Constitution. Even if retroactive certification of Rowe is accepted, an exercise of restraint could have avoided the invocation of res judicata. If Johnson had limited its retroactive certification of Rowe to the issues of liability and injunctive relief, as the Rowe court could have done under rule $23(\mathrm{c})(4)(\mathrm{A}){ }_{0}^{42}$ res judicata would not have barred Johnson's monetary claims. ${ }^{43}$ Absent class members should be bound only by those issues certified for class action. ${ }^{44}$

Inadequacy of representation by the class representatives in Rowe provides the other nonconstitutional ground upon which the Fifth Circuit could have decided Johnson.45 Although adequate representation is, of course, a constitutional requirement, it is also required by rule $23(\mathrm{a})(4)$. The plaintiffs in the earlier action had settled their individual monetary claims for $\$ 1,000$ each but had failed to seek any monetary relief for other members of the class whom they were allegedly representing. ${ }^{48}$ Although there may be some question as to how strictly the court, on collateral attack, should apply the rule requiring adequate representation, ${ }^{47}$

485 F.2d at 446. The same cannot be said of Johnson. Johnson could not be estopped to deny the class action nature of the suit. He had had no notice of the action and should not be held to have acquiesced in something of which he had no knowledge. Second, Bing was still in litigation when the class action was retroactively certified. Rowe had been closed at least seven years by the time of Johnson. Certification by implication requires an appellate court to assume many of the fact-finding duties of a trial court. In particular, the appellate court must. determine the type of class action that may be maintained and the identity of the class and its members. Such a task is accomplished more accurately while the litigation is still in progress than seven years later, when the court must operate from an old and cold record.

42 See FED. R. Grv. P. 23(c)(4)(a), note 1 supra.

43 The complaint in Rowe sought only injunctive relief for the class. The only back pay requests were individual claims by the three class representatives. The decree granted by the appellate court did not mention class back pay awards. Rowe v. General Motors Corp., 4 Emp. Prac. Dec. 17715 (N.D. Ga. 1969), rev'd and remanded, 457 F.2d 348 (5th Cir. 1972).

44 This rationale was utilized in Bogard v. Cook, 586 F.2d 399 (5th Cir. 1978), cert. denied, $100 \mathrm{~S}$. Ct. 173 (1979). The court held that a prisoner's claims for monetary relief were not barred by an earlier class action which did not consider monetary relief. The court stated that "[g]iven the lack of common questions of fact as to many [individual monetary] claims, and the unmanageability of the suit had they been included, we cannot believe that the district court would have allowed the claims as part of that action if they had been potentially possible [sic]." Id. 409. Jones-Bey v. Caso, 535 F.2d 1360 (2d Cir. 1976), also seems to have used a similar rationale in a similar case. The extremely short discussion by the Second Circuit, however, makes it difficult to ascertain the precise reasoning followed by the court.

45 This argument, although raised by Johnson, see note 18 supra, was not resolved by the court. Johnson, 598 F.2d at 438.

46 Id. 434.

47 See Collateral Attack, supra note 32, at 604, which argues that a de novo review of the trial court's determination of adequate representation is too broad, 
it seems clear that the court would have had to agree with Johnson on this issue. Because the Rowe plaintiffs did not attempt to represent absent class members' monetary claims at all, it is hard to say that they did so "adequately." 48

\section{An Evaluation of the Johnson Holding}

Johnson was not based on an interpretation of rule 23.49 The Fifth Circuit based its opinion upon a due process case decided by the Supreme Court, ${ }^{50}$ Mullane v. Central Bank \& Trust Co. ${ }^{51}$ Johnson also cites Eisen $v$. Carlisle \& Jacquelin, ${ }^{52}$ in which the Supreme Court required individual notice to all identifiable members of a (b)(3) class. Although some language in Eisen sug-

and suggests that class members should be relieved of the binding effect of the earlier class action only upon a showing that the judge in the earlier action abused his discretion when he found that the named plaintiffs adequately represented the class.

Some courts have applied the standard of adequate representation to determine the res judicata effect of an earlier class action. The leading case doing so is Gonzales v. Cassidy, 474 F.2d 67 (5th Cir. 1973). See also Alexander v. Aero Lodge No. 735, 565 F.2d 1364 (6th Cir. 1977), cert. denied, 436 U.S. 946 (1978); Research Corp. v. Edward J. Funk \& Sons Co., 15 F.R. Serv. $2 d 580$ (N.D. Ind. 1971).

48 But see International Prisoners' Union v. Rizzo, 356 F. Supp. 806 (E.D. Pa. 1973). The court adopted a rather low standard of adequate representation, requiring only a community of interests between representatives and class members. It then held that the class representatives' failure to raise a damage claim which should have been raised to avoid a "splitting of a cause of action" had a "de minimis impact on the representation issue." Id. 809. However, a holding that there was adequate representation in Rowe would amount to supplying a defendant with the power to preclude litigation of the rights of absent class members by buying off the class representatives. Cf. Deposit Guaranty Nat'l Bank v. Roper, 100 S. Ct. 1166, 1174 (1980) ("To deny the right to appeal [from a district court's denial of class action certification] simply because the defendant has sought to buy off the individual private claims of the named plaintiffs would be contrary to sound judicial administration.").

49 Only three subdivisions of the rule mention notice: (e), (c)(2), and (d)(2).

See note 1 supra. Subdivision (e) applies only to notice of proposed dismissal or settlement of the class action. Subdivision (c)(2) applies only to class actions maintained under subdivision (b)(3). Subdivision (d)(2) applies to all class actions, including the monetary (b) (2) actions in question in Johnson. However, subdivision (d) is a list of orders which a court may make, not those which it is required to make. This point was emphasized by the Advisory Committee when it stated that subdivision (d)(2) "does not require notice at any stage, but rather calls attention to its availability and involves the court's discretion." Anvisony Comm. Note, supra note 32, at 106. But see Arey v. Providence Hosp., 55 F.R.D. 62,71 (D.D.C. 1972) (broad language of rule $23(\mathrm{c})(2)$ indicates policy of drafters regarding (b)(1) and (2) class actions).

50 Johnson v. General Motors Corp., 598 F.2d 432, 437 (5th Cir. 1979) (quoting Eisen v. Carlisle \& Jacquelin, 417 U.S. 156, 174 (1974): "Notice and an opportunity to be heard are "fundamental requisites of the constitutional guarantee of procedural due process." ").

51339 U.S. 306 (1950).

52417 U.S. 156 (1974). 
gests that its result may have been required by Mullane, ${ }^{53}$ the stated basis of the decision is the Court's construction of rule $23 . .^{54}$ The applicability of Mullane to class actions, particularly to (b)(2) actions, will thus be the initial focus of attention in our effort to determine whether notice to absent class members is constitutionally required.

\section{A. The Mullane and Hansberry Decisions}

Mullane involved a proceeding brought by the trustee of a common trust fund for a settlement of accounts. ${ }^{55}$ The effect of the proceeding was to terminate "every right which beneficiaries would otherwise have against the trust company . . . for improper management of the common trust fund during the period covered by the accounting." ${ }^{56}$ The pertinent state statute required the presence of two guardians at the proceeding: one guardian to represent all the income beneficiaries and another to represent those beneficiaries interested in the principal of the common fund. ${ }^{57}$ Although Mullane was not a class action, its language is broad enough to apply to such actions:

An elementary and fundamental requirement of due process in any proceeding which is to be accorded finality is notice reasonably calculated, under all the circumstances, to apprise interested parties of the pendency of the action and afford them an opportunity to present their objections. ${ }^{58}$

53 Id. 173-75.

54 'We are concerned here only with the notice requirements of subdivision (c) (2), which are applicable to class actions maintained under subdivision (b)(3). By its terms subdivision (c) (2) is inapplicable to class actions for injunctive or declaratory relief maintained under subdivision (b)(2)." Id. 177 n.14.

Sosna v. Iowa, 419 U.S. 393 (1975), provides strong inferential support for the view that Eisen should be read solely as a construction of rule $23(\mathrm{~b})(3)$. The Court, per Justice Rehnquist, stated that because a rule 23(b)(2) action was contemplated by the plaintiff in Sosna, "the problems associated with a rule 23(b)(3) class action, which were considered by this Court last term in [Eisen], are not present in this case." Id. 397 n.4. Although the Court in Sosna was dealing with a request for injunctive rather than monetary relief, there is no hint that the Court's view on the applicability of Eisen was dependent on the form of relief sought.

Many authorities agree that the Eisen holding should be interpreted as a construction of rule 23. See, e.g., 3B MoORE's Federal Practice $\uparrow 23.55$ (2d ed. 1978); 2 Newberg on Class Actions $\$ 2225$ (1977); Dam, supra note 2, at 110; Developments in the Law-Class Actions, 89 Harv. L. REv. 1318, 1402 (1976) [hereinafter cited as Developments].

55 Mullane, 339 U.S. at 306.

56 Id. 311.

57 Id. 310.

58 Id. 314. 
Upon these principles, the Supreme Court held, inter alia, that the statutory notice by publication was insufficient for the beneficiaries whose whereabouts were known. Due process required notification by ordinary mail at the very least. ${ }^{59}$

Mullane is not the sole relevant Supreme Court decision. In Hansberry $v . L e e^{60}$ the Court stated in dicta that a judgment in a class action could bind absentee members of the class. Due process was satisfied not by individual notice, but by adequate representation of absent class members. ${ }^{\circ 1}$ The earlier class action in Hansberry did not meet that standard because the class representatives had interests which conflicted with those of the other class members: "Such a selection of representatives for purposes of litigation, whose substantial interests are not necessarily or even probably the same as those whom they are deemed to represent, does not afford that protection to absent parties which due process requires." 62

The relative importance of adequate representation to the question whether due process is being afforded in a class action has been a matter of considerable dispute. Four possible relationships, derived from the interaction of the notice and adequate representation concepts, may satisfy the requirement of due process: (I) Both notice and adequate representation are necessary-neither alone is sufficient; (2) notice alone is necessary and sufficient; (3) adequate representation alone is necessary and sufficient; (4) either notice or adequate representation is sufficient-the combination is not necessary. In holding that notice is necessary to bind absent parties, the Johnson court adopted either the first or second of the above positions. The analysis below argues that the Johnson approach is wrong, and that the third position is correct.

B. Does Mullane Require Notice in (b)(2) Proceedings for Monetary Relief?

Before proceeding to discuss the necessity of notice, it is profitable to dispose of the question whether notice alone is sufficient to satisfy the demands of due process. This question is most clearly presented in cases in which notice was given but in which representation in the earlier class action was inadequate; in such a case, is notice alone sufficient to bind absent class members, or should

50 Id. 319.

C0 311 U.S. 32 (1940).

61 Id. $40-41,42-43$.

62 Id. 45. 
they be able to allege lack of due process for want of adequate representation in the earlier suit? Because the precise dimensions of this issue are beyond the scope of this Comment, it will suffice here to point out that a number of authorities have reached some agreement on the issue, concluding that due process does indeed require adequate representation. ${ }^{63}$ Notice is merely "an additional safeguard; its purpose is to buttress the requirement of adequate representation." 64 Hence, notice alone is not sufficient. We turn now to consider whether adequate representation alone is sufficient, or whether notice is constitutionally mandated.

Notice is not constitutionally required in all class actions if Hansberry, and not Mullane, is controlling in the class action situation. The majority of authorities have reached the conclusion that, indeed, Hansberry is controlling, and that therefore notice is not necessary in all class actions. ${ }^{65}$ The Johnson court implicitly accepted this argument to the extent that only injunctive or declaratory relief was sought in the class action. ${ }^{66}$ When damages were sought, though, the court applied Mullane and determined that notice is a requirement of due process. ${ }^{67}$ This approach cannot be justified. Mullane does not control the class action situation, regardless of the remedy sought.

The first major distinction between the Mullane situation and the rule 23 class action is that in Mullane no party had an economic incentive to represent adequately the interests of the absent beneficiaries. The trustee certainly did not-in the accounting he became an adversary of the beneficiaries. ${ }^{68}$ And although the opinion does not specifically state how the guardians were compensated, a conflict of interest with the beneficiaries was highly

63 See, e.g., Gonzales v. Cassidy, 474 F.2d 67, 76 (5th Cir. 1973); Being Adequate, supra note 23, at 1231; Collateral Attack, supra note 23, at 605-06. But see In re Four Seasons Sec. Laws Litigation, 502 F.2d 834 (10th Cir.), cert. denied, 419 U.S. 1034 (1974) (notice alone satisfies due process).

64 Being Adequate, supra note 23, at 1231. See also Developments, supra note 54 , at 1403 .

65 Some cases and comments have explicitly distinguished Mullane to reach this result. See, e.g., Wetzel v. Liberty Mut. Ins. Co., 508 F.2d 239, 256 (3d Cir.), cert. denied, 421 U.S. 1011 (1975); 2 NEWBERG ON CEASS ACTIONS $\$ 2300 \mathrm{a}$ (1977); Developments, supra note 54, at 1413-16; Note, Eisen v. Carlisle \& JacquelinFluid Recovery, Minihearings and Notice in Class Actions, 54 B.U. L. Rev. 111, 139 (1974) [hereinafter cited as Fluid Recovery]; Adequate Representation, supra note 32 , at $912-15$. See also note 32 supra.

60 "[A]n absent class member is bound by the res judicata effect of a (b) (2) class action to the extent that the judgment concerns injunctive or declaratory relief, even when no notice was provided." 598 F.2d at 438.

67 See note 86 infra \& accompanying text.

68339 U.S. at 316. 
probable. $^{69}$ If they were compensated on a standard-fee basis, their advocacy would probably have been less aggressive than that of the typical plaintiff's class action attorney who works on a contingent-fee basis. If the guardians charged hourly fees, to be paid out of the trust, the tendency would be to litigate excessively and thus subject the beneficiaries' interests in the trust "to diminution in the proceeding by allowance of fees and expenses to one who, in their names but without their knowledge, may conduct a fruitless and uncompensatory contest." 70 A similar situation could never arise in a class action. If a plaintiff whose interests conflict with those of potential class members attempts to file an action under rule 23, certification would be denied for failure to satisfy the prerequisite of subdivision (a)(4), mandating that the representative parties "fairly and adequately protect the interests of the class." 71 Subdivision (a)(4) applies to all class actions, and so distinguishes the $23(\mathrm{~b})(2)$ proceeding from that in Mullane, regardless of the remedy sought.

A second and more important distinction is that the special powers granted the trial judge under rule $23^{72}$ make it far more likely that representation will be constitutionally adequate ${ }^{73}$ in a

69 See similar analysis in Wetzel v. Liberty Mut. Ins. Co., 508 F.2d 239, 256 (3d Cir.), cert. denied, 421 U.S. 1011 (1975); Adequate Representation, supra note 32 , at 912-13.

70339 U.S. at 313.

71 Fed. R. Crv. P. 23(a)(4). See note 1 supra.

$72 \mathrm{See}$ id. These powers include: the power under subdivision $(c)(3)$ to define the class so as to omit those persons who would not be adequately represented; the power under subdivision (c)(4)(a) to limit the action's certification so as to foreclose consideration of those issues, such as individual damages, which may not be susceptible to adequate class representation; the power under subdivision (c) (4) (b) to create subclasses in order to avoid representation of conflicting interests, and the power under subdivision (d)(2) to order that some or all class members be notiffed of the opportunity to signify whether they consider the representation to be fair and adequate. See FED. R. Crv. P. 23, note 1 supra.

73 It is unfortunate that the language used in subdivision (a)(4), that representatives must "adequately protect" the interests of the class members, is similar to the language the Supreme Court used in Hansberry to describe the constitutional requirement of adequate representation. To avoid confusion, this Comment uses the term "constitutionally adequate" to distinguish the due process concept from the concept of initially determining the quality of the named class representatives under rule 23(a)(4).

The difference between the two concepts is clear when one considers that the (a) (4) determination must be made at the outset of the litigation, before a judge can possibly know whether the representation will turn out to be constitutionally adequate. The court must use its various powers under rule 23 , see note 72 supra, to try to ensure that the representation meets constitutional requirements. Final determination of whether the representation was in fact constitutionally adequate must await collateral attack. See Advisory Comm. Note, supra note 31, at 106: "Subdivision (c)(3) does not disturb the recognized principle that the court conducting the action cannot predetermine the res judicata effect of the judgment; this can be tested only in a subsequent action." 
class action than it was in the Mullane proceeding. Professor Moore states that "the representative lawsuit under revised rule 23 has developed into a quasi-administrative proceeding, conducted by the judge. This departure from the traditional view of litigation as a strict adversary proceeding calls for a revised attitude toward the parties and their advocates." "74 The lack of similar judicial power in Mullane necessitated reliance on the adversary model to assure the adequacy of representation. The parties had to be given notice so that, if necessary, they could intervene and represent themselves. ${ }^{75}$ This distinction between Mullane and the (b)(2) proceeding again applies regardless of the remedy sought. In sum, both of the above distinctions between Mullane and the class action situation apply with equal force regardless of the relief sought. The Johnson court, it seems, is therefore unjustified in relying on Mullane for its holding that, to be bound by a (b)(2) action for monetary relief, each class member must be afforded notice. ${ }^{76}$

\section{A Better Test for Invoking the Notice Requirement: The Nature of the Class}

By focusing on the nature of the relief sought, the Johnson court missed the more important and useful criterion for determining when to require notice: the nature of the class seeking relief.

The idea that there are two levels of "adequate representation" was recognized by the Ninth Circuit in Souza v. Scalone, 563 F.2d 385, 386 (9th Cir. 1977), in which the court explained that the adequacy of representation could be measured against "a finer tuned scale" (the Constitution) or "the coarser scale of Rule $23(\mathrm{a})(4)$."

74 3B Moore's Federal Practice $\{$ 23.45[4.-5] (2d ed. 1978).

75 See Developments, supra note 54, at 1414-16.

76 In addition to the discussions of Mullane and Eisen, it must be noted that the Fifth Circuit felt that Bogard v. Cook, 586 F.2d 339 (5th Cir. 1978), cert. denied, 100 S. Ct. 173 (1979), "largely control[led]" Johnson. 598 F.2d at 437. Reliance on Bogard, however, is misplaced. In Bogard, the court held that a prisoner's claim for damages was not barred by the res judicata effect of a prior class action which had sought only injunctive relief. One basis for its result was that the notice given in the class action was "insufficient to alert prisoners to the possibility that they could seek individual money damages for personal wrongs." 586 F.2d at 408 . Johnson implies that Bogard applied due process principles, 598 F.2d at 497, but Bogard did not even mention due process. It merely noted that "[p]rinciples of res judicata are not ironclad," and that it would be "harsh and improper" to apply res judicata to Bogard's circumstances. $586 \mathrm{~F} .2 \mathrm{~d}$ at 408 .

The Bogard opinion also suggests an alternative ground for its result similar to that discussed in notes 42-44 supra \& accompanying text. Bogard's monetary claims were not barred because they could not have been raised in the class action. Bogard's most serious injury had occurred two months after the record was closed in that proceeding. Id. 408. Furthermore, the Bogard court doubted that the district court in the class action would have allowed damage claims, because they would have made the class action unmanageable. Id. 409 . 
The differences in the natures of typical classes in (b)(2) as opposed to $(b)(3)$ proceedings illustrate the value of utilizing this rather than the Johnson approach.

At base, the (b)(2) class is distinguished from the (b)(3) class by class cohesiveness. Unlike many (b)(3) class actions, the (b)(2) class action is ordinarily not suspectible to criticism as a "Frankenstein monster posing as a class action." 77 Subdivision (b)(3) is a broad category permitting class actions in diverse situations. ${ }^{78}$ Its basic goal, "economies of time, effort and expense," 79 is achieved by the aggregation of individual claims weighted heavily with common questions of law and fact. ${ }^{80}$ Subdivision (b)(2), on the other hand, was designed primarily for facilitating class actions in the civil rights area. ${ }^{81}$ Injuries remedied through (b)(2) actions are really group, as opposed to individual, injuries. ${ }^{82}$ The members of a (b)(2) class are generally bound together through "preexisting or continuing legal relationships" 83 or by some significant common trait such as race or gender. ${ }^{84}$ Although the interests of

77 Eisen v. Carlisle \& Jacquelin, 391 F.2d 555, 572 (2d Cir. 1968) (Lumbard, J., dissenting). Antidiscrimination Class Actions, supra note 31 , at $878-79$, details how the numerosity generally required of class actions is often distorted or disregarded in certification of (b) (2) employment discrimination class actions.

78 Subdivision (b) (3) "permits a class action in diverse situations where the only limit is that the class action be a better method of settling the controversy." FED. R. Crv. P. 23(b)(3), note 1 supra. Note, Rule 23: Categories of Subsection (b), 10 B.C. IND. \& CoM. L. REv. 539, 545 (1968).

79 Advisory Comm. Note, supra note 31, at 102-03. For an extreme position on this aspect of (b) (3) class actions, see Weithers, Amended Rule 23: A Defendant's Point of View, 10 B.C. IND. \& CoM. L. Rev. 515, 518 (1968) (courts should avoid certifying (b) (3) actions "unless the basic goal of efficiency is achieved through the avoidance of multiplicity of litigation.").

80 See generally Kaplan, Continuing Work of the Civil Committee: 1966 Amendments of the Federal Rules of Civil Procedure (pt. I), 81 HARv. L. Rev. 356 (1967). Professor Kaplan explains that the (b) (3) class action was "a new category deliberately created," id. 399 , to deal with "the recurrent cases where a party's act or omission has radiated outward to affect a large number of people . . . ." Id. 389. "The object [of (b)(3)] is to get at the cases where a class action promises important advantages of economy of effort and uniformity of result without undue dilution of procedural safeguards for members of the class or for the opposing party." Id. 390. The article also provides insight into the Committee's concerns with creating class actions like (b) (3) that are much more complex than the "natural" class action, like those brought under (b)(1) and (2). See id. 375-400.

81 See, e.g., Advisory Comm. Note, supra note 31, at 102; 7A C. Wrichr \& A. Mrler, Federal Practice and Procedure \$\$ 1775, 1776 (1972).

82 The requirement of (b) (2) that the opposing party must act or refuse to act on grounds "generally applicable" to the entire group may be satisfied by discriminatory conduct against any one member of the group. See Advisory Comm. Note, supra note 31, at 102; 3B Moore's Federar Practice If 23.40[2] (2d ed. 1978); Note, Rule 23: Categories of Subsection (b), supra note 78, at 544.

83 See 7A C. Wrught \& A. Mrrer, supra note 81, at \$1786.

84 See Alexander v. Aero Lodge No. 735, 565 F.2d 1364, 1372 (6th Cir. 1977): "As we stated in Senter v. General Motors Corp., [532 F.2d 511, 524 (6th Cir. 
the different members of a (b)(2) class are by no means identical, the substantial cohesion of those interests makes it likely that representative members can adequately represent the interests of absent members and that the need for and interest in individual representation will be minimal. ${ }^{85}$ Under such circumstances, the contribution that individual notice can make to buttressing adequate representation is not great enough to warrant a mandatory procedural or constitutional requirement.

Johnson seems to accept this distinction to the extent that only injunctive or declaratory relief is sought by the (b)(2) class. In so doing, Johnson implies that monetary relief is destructive of the cohesion that normally obviates the need for notice. ${ }^{86}$ With cohesion thus weakened, the (b)(2) monetary action becomes almost indistinct from the (b)(3) action, making notice necessary.

This proposition is not convincing. The notion that a request for damages automatically destroys (b)(2) class cohesion rests on the assumption that monetary relief cannot be granted without conducting a trial-like procedure on each class member's individual damages. ${ }^{87}$ The assumption ignores the possibility of individualized

1976)], 'Race discrimination is peculiarly class discrimination . . . The class here is homogeneous, as the discrimination in employment is claimed in all instances to be on the basis of one common characteristic, the race of the employee." See also Antidiscrimination Class Actions, supra note 31 , at 884-88 (subdivision (b)(2) classes are distinct "entity classes," defined by preexisting common characteristics such as race or sex).

85 See Wetzel v. Liberty Mut. Ins. Co., 508 F.2d 239, 247-49, 256-57 (3d Cir.), cert. denied, 421 U.S. 1011 (1975); Larionoff v. United States, 533 F.2d 1167, 1168 n.44 (D.C. Cir. 1976) (discussing (b)(2) in conjunction with (b) (1) class actions); 7A C. WruGHT \& A. MrreER, supra note 81, at \$1786; Miller, supra note 32, at 315-16; Advisory Comm. Note, supra note 31, at 106; Being Adequate, supra note 32, at 1234; Note, Managing the Large Class Action: Eisen v. Carlisle \& Jacquelin, 87 Harv. L. Rev. 426, 440-41 (1973). But see 37 Orro St. L.J. 386 (1976).

The distinctions between (b) (2) and (b) (3) class actions may confront the basic theoretical underpinnings of the class action. See Developments, supra note 54 , at $1320-72$.

86 The court stated:

When only equitable relief is sought in an action involving a cohesive plaintiff group such as a class of black employees at an assembly plant, the due process interests of absent members will usually be safeguarded by adequate representation alone. As the Advisory Committee on Rule 23 stated, "[i]n the degree that there is cohesiveness or unity in the class and the representation is effective, the need for notice to the class will tend toward a minimum." Where, however, individual monetary claims are at stake, the balance swings in favor of the provision of some form of notice.

598 F.2d at $437-38$ (citation omitted).

87 Cf. Robinson v. Union Carbide Corp., 544 F.2d 1258, 1263 (5th Cir.) (Wisdom, J., concurring), cert. denied, 434 U.S. 822 (1977). 
injunctive relief ${ }^{88}$ as well as the broad discretion trial courts have in calculating and disbursing damage awards. ${ }^{89}$ Courts are able to fashion mechanisms to deal with monetary awards that avoid fragmentation of the class action into individualized proceedings. The rationale for a class-wide award was described by the Fifth Circuit in the leading case of Pettway v. American Cast Iron Pipe Co.: ${ }^{80}$

The method of computation will be a function of the complexity of the case. If the class is small, or the time period short, or the effect of the discrimination straightforward, a fairly precise determination of what each claimant's position would have been, but for the discrimination, is possible....

However, when the class size or the ambiguity of promotion or hiring practices or the multiple effects of discriminatory practices or the illegal practices continued over an extended period of time calls forth [a] quagmire of hypothetical judgment[s] . . . a class-wide approach to the measure of back-pay is necessitated.

Certain types of suits, such as title VII actions alleging discrimination in promotion policy, are very amenable to class-wide relief. Precise proof of individual damages, utilizing a "but for" standard of proof, is almost impossible. Speculation that one employee would have been promoted instead of another cannot be a fair and rational basis for any award. ${ }^{91}$ "The great purpose of the back pay award, to make whole the innocent victim of discrimination, can be fulfilled only by taking a pragmatic view of the standards of proof . . ." 92 When proof of individual damages has been

88 See, e.g., Pettway v. American Cast Iron Pipe Co., 494 F.2d 211, 257 (5th Cir. 1974):

The objection that back pay will vary from class member to class member is not overriding. Once class-wide discrimination has been demonstrated to result in disproportional earnings, a class-wide decision that back pay is appropriate can be discerned without deciding which members of the class are entitled to what amounts [citation omitted]. This is no different than affirmative injunctive relief, in the form of red circling or advance entry, which on remand will be applied to particular individuals and not the whole class.

89 See, e.g., Gross, Remedies in Discrimination Gases, 29 N.Y.U. CoNF. LAB. 129, 138-39 (1976); Developments, supra note 54, at 1516-36.

90494 F.2d 211, 261 (5th Cir. 1974) (emphasis added).

91 See id. 262 n.152.

92 Davidson, "Back Pay" Awards Under Title VII of the Civil Rights Act of 1964, 26 Rutgers L. Rev. 741, 766-67 (1973). See also Blumrosen, Wage Discrimination, Job Segregation and Title VII of the Civil Rights Act of 1964, 12 U. Mrch. J. L. REF. 397, 495-98 (1979); C.A.R. Comment, 4 Class Acrion ReP. 178 
wholly speculative, courts have based back-pay awards on the job histories of adjacent persons on the seniority list, ${ }^{93}$ the averaging of pay rates, ${ }^{94}$ and the maximum scale of wages or salaries which could have been earned. ${ }^{95}$ Although an individualized remedy is preferred, ${ }^{96}$ courts should make use of their equitable powers to calculate damages without requiring "unrealistic exactitude." 97 In such cases it suffices for the trial court to determine the amount of back wages "as a matter of just and reasonable inference." 98

In fixing class-wide damages, a court balances the interest of compensating victims of discrimination and vindicating public policy against the employer's interest in not paying punitive damages. At the same time, the court should be wary of awarding windfalls to persons who have not been injured.99 In sum, there are simply too many relevant considerations, many of them related to the facts of each individual case, to justify the generalization by an appellate court that notice is constitutionally required whenever monetary claims are at stake. This is not to imply, however, that there is no correlation between the utility of notice and the form of relief sought. When only injunctive relief is requested, the relevant facts usually relate to a general pattern of conduct by the defendant. Because class members

(1975). But see Bamard, Title VII Class Actions: The "Recovery Stage," 16 WM. \& MARY L. Rev. 507, 512-17 (1975) (back pay awards without proof of individual injury are punitive and an abuse of equitable powers); Mott, Harnessing Class Back Pay Relief Under Title VII: A Return to the Theory of Compensation, 4 CLAss ACTION REP. 169 (1975).

93 See, e.g., Bowe v. Colgate-Palmolive Co., 489 F.2d 896, 902-04 (7th Cir. 1973); United States. v. Wood, Wire \& Metal Lathers Local 46, 328 F. Supp. 429, 443-45 (S.D.N.Y. 1971).

94 See, e.g., Stamps v. Detroit Edison Co., 365 F. Supp. 87, 121-22 (E.D. Mich. 1973), rev'd on other grounds sub nom. EEOC v. Detroit Edison Co., 515 F.2d 301 (6th Cir. 1975), vacated, 431 U.S. 951 (1977). But see Ralston v. Volkswagenwerk, A.G., 61 F.R.D. 427, 431-33 (W.D. Mo. 1973) (rejecting use of averages in distributing damages in (b) (3) antitrust class action).

95 See, e.g., Stewart v. General Motors Corp., 542 F.2d 445, 453 (7th Cir. 1976), cert. denied, 433 U.S. 919 (1977); Bowe v. Colgate-Palmolive Co., 489 F.2d 896 (7th Cir. 1973).

96 See Stewart v. General Motors Corp., 542 F.2d 445, 452 (7th Cir. 1976), cert. denied, 433 U.S. 919 (1977) ("an individualized remedy . . . will best compensate the victims of discrimination without unfairly penalizing the employer").

97 Pettway, 494 F.2d at 260-61. Accord, Ostapowicz v. Johnson, 541 F.2d 394, 400 (3d Cir. 1976); Hairston v. McLean Trucking Co., 520 F.2d 226, 232-33 (4th Cir. 1975). Cf. Albemarle Paper Co. v. Moody, 422 U.S. 405, 417 (1975) ("primary [prophylactic] purpose" of back pay awards limits trial judge's discretion to deny awards).

98 Brennen v. City Stores, Inc., 479 F.2d 235, 242 (5th Cir. 1973) (quoting Anderson v. Mt. Clemens Pottery Co., 328 U.S. 680, 687 (1946)).

99 Because doubts are construed against the guilty employer, this process usually favors an award. See Stewart v. General Motors Corp., 542 F.2d at 453. 
are unlikely to have much significant information not already known to the representatives, notice may be of little benefit. In a suit for damages, on the other hand, relevant information pertaining to individual injuries is probably unknown to the class representative. Notification capable of eliciting such information would be beneficial in these cases. Although this correlation is not perfect, ${ }^{100}$ it is sufficiently substantial to be relevant to a trial judge considering whether he should order notification of absent members.

\section{Discretionary Notice Under Subsection (d)(2)}

The foregoing sections argue that due process in (b) (2) class actions, regardless of the relief sought, is satisfied by adequate representation. Notice need not be provided in every (b) (2) action seeking monetary relief but, as subsection (d) (2) provides, should be ordered at the discretion of the trial court.101 This section of the Comment outlines, in a very general way, the types of considerations of which the court should take cognizance in exercising this discretion.

In essence, the proper exercise of discretion necessitates balancing, on an ad hoc basis, the benefits of notice to the absent class members against the consequent burdens to the class representatives and, in turn, to the enforcement of public policy. ${ }^{102}$ The two major benefits ${ }^{103}$ are the notification of class members of their

100 In some class actions involving monetary claims all of the information necessary in order to award monetary relief will be obtainable by the class representative from the defendant's records. It is also possible that some non-monetary class actions would benefit greatly by using notice to elicit information from absent class members.

101 FED. R. Crv. P. 23(d)(2), note I supra.

102 In a different context, the Supreme Court has written that "due process is flexible and calls for such procedural protections as the particular situation demands." Morrissey v. Brewer, 408 U.S. 471, 481 (1972). Whether due process requires certain procedural safeguards may be determined by balancing, among other things, the public and private interests at stake, and "the probable value, if any, of additional or substitute procedural safeguards." Matthews v. Eldridge, 424 U.S. 319, 334-35 (1976).

$103 \mathrm{~A}$ third benefit of notice in (b) (3) class actions is notification of the right to "opt out." See FED. R. Crv. P. 23(c)(2), note 1 supra. Such a benefit generally does not exist in (b)(2) actions, however. See FED. R. Crv. P. 23(c) (3), note I supra. Most authorities and courts agree that class members may exclude themselves from (b) (2) class actions only under special circumstances, as the court's discretion may allow. See, e.g., 3B MOORE's FEDERAL Practice \ 23.40[4] (2d ed. 1978); 2 Newberg on Crass Actions $\$ 2560$ (a) (1977). The Fifth Circuit, however, has at least twice permitted (b) (2) class members to opt out. See Bogard v. Cook, 586 F.2d 399, 407 (5th Cir. 1978), cert. denied, 100 S. Ct. 173 (1979); Pettway v. American Cast Iron Pipe Co., 494 F.2d 211, 263 n.154 (5th Cir. 1974). See also DeGier v. McDonald's Corp., 76 F.R.D. 125 (N.D. Cal. 1977); Women's 
rights to intervene and the solicitation of useful information from the unnamed class plaintiffs. ${ }^{104}$ The financial burdens of notice on the representative parties ${ }^{105}$ and the social cost to society of discouraging the private enforcement of public policies ${ }^{106}$ are the two major elements to be weighed against the benefits of providing notice.

Certain factual circumstances in a given case will, however, lessen the relative importance of one or more of these factors. Providing notice of the opportunity to intervene will not be significantly beneficial where it is unlikely that any class members would be motivated to intervene. ${ }^{107}$ Such will be the case when the class is very cohesive and will thus be willing to trust the named plaintiffs to represent them, or when the potential individual recovery is so small that it makes personal legal representation financially prohibitive.

The impact of the solicitation of information will be minimized in two common situations. First, when the reward for responding to notice is uncertain because liability has not yet been adjudicated and the potential individual recovery is small, a large percentage of the class members may not respond to the notice. 108

Comm. for Equal Employment Opportunity v. National Broadcasting Co., 71 F.R.D. 666 (S.D.N.Y. 1976).

104 Information can be useful in two ways. First, it may inform the class representatives of new facts, claims, or arguments that will improve the substantive case for the class. Second, the information may aid the judge in administering the class action and in ruling on such matters as class certification, subclasses, class definition and adequacy of representation. See, e.g., Robinson v. Union Carbide Corp., 544 F.2d 1258, 1261-65 (5th Cir.) (Wisdom, J., concurring), cert. denied, 434 U.S. 822 (1977); Arey v. Providence Hosp., 55 F.R.D. 62, 71 (D.D.C. 1972).

105 Although the main burden related to notice is its cost, in uncommon circumstances notice may strain the relationships in the community that are bound up with the class action. See Johnson v. City of Baton Rouge, 50 F.R.D. 295 (D. La. 1970) (notice by publication of a suit alleging discriminatory police practices against blacks denied because it might have inflamed race relations in the community).

106 The social cost of deterring constitutional or statutory class actions has been explicitly acknowledged by courts when considering whether notice should be sent. See Bachman v. Collier, 73 F.R.D. 300, 306 (D.D.C. 1976); Redhail v. Zablocki, 418 F. Supp. 1061, 1067 (E.D. Wis. 1976), aff'd, 434 U.S. 374 (1978); Watson v. Branch County Bank, 380 F. Supp. 945, 959 (W.D. Mich. 1974).

107 Notice is also unnecessary for this reason when the entire class is already aware of the action and of its right to intervene. See Mungin v. Florida R.C. Ry., 318 F. Stupp.. 720, 732 (M.D. Fla. 1970), aff'd per curiam, 441 F.2d 728 (5th Cir.), cert. denied, 404 U.S. 897 (1971) (notice of the possibility of separate representation held unnecessary because it was clear that members of the class were already informed).

108 Motivation by threat rather than by reward is not permissible. Notice containing an "opt in" provision, requiring class members either to respond to notice or to forfeit their share in any recovery, has been held improper. See, e.g., Robinson v. Union Carbide Corp., 544 F.2d 1258, 1260-61 (5th Cir.), cert. denied, 434 U.S. 822 (1977). Given the perceived lack of financial reward for responding, or 
Second, any information which is received will be of very little value when almost all of the relevant facts are already known by the class representatives or are easily obtainable from the defendant's records, such as an employer's hiring and promotion records.

The cost of notice-a factor mitigating against an order requiring notice-will be relatively small when the notice can be given through means other than individually mailed letters. Notices can be posted on employee or union bulletin boards, read over an intercom system, or included in the plant or company newspaper. ${ }^{109}$ Lesser savings can be realized by including printed notices in some of the defendant's periodic mailings to the plaintiff class, such as credit card billings or governmental social insurance monthly payments. ${ }^{110}$ Court orders under 23 (d) (2) directed to the defendant may be necessary to effect notice by one of these alternate means.111

The potential social costs resulting from the inability or unwillingness of the representatives to proceed with litigation will not be present, of course, where the representative plaintiffs are both willing and able to pay for notice. ${ }^{112}$ This will likely be the case when the size of the class or the means of giving notice make the expenses insignificant, or when the resources of the class representatives and the potential monetary recovery are substantial.

\section{CONCLUSION}

The factors noted in the preceding section are hardly meant to be exhaustive of the list of elements which a trial court might want to consider when, under rule 23 (d) (2), it decides whether or or not to order notice in a rule 23 (b) (2) class action. Rather, the foregoing discussion seeks to emphasize the mistake that the Johnson court made when it held that the res judicata effect of (b) (2)

absence of threat to a potential award by not responding, a large percentage of class members may not take the time to respond to notice. See, e.g., Korn v. Franchard Corp., 456 F.2d 1206, 1210 (2d Cir. 1972), where $75 \%$ of the class failed to respond to a notice requesting individual damage claim statements prior to adjudication of liability.

100 See, e.g., Fujishima v. Board of Educ., 460 F.2d 1355, 1360 (7th Cir. 1972) (posted or intercom announcements); Collins v. Schoonfeld, 344 F. Supp. 257 (D. Md. 1972) (posted announcements); Ellison v. Rock Hill Printing \& Furnishing Co., 64 F.R.D. 415, 417-18 (D.S.C. 1974) (plant newspaper).

110 Cf. Eisen v. Carlisle \& Jacquelin, 417 U.S. 156, 180 n.1 (1974) (Douglas, J., dissenting in part) (individual notice could in certain instances be effectuated through the least burdensome means, such as billing statements and payroll deduction plans).

111 Fed. R. Crv. P. 23(d)(2), note 1 supra.

112 The burden is also relieved when notice can be charged to the defendant after he has been found liable. See note 27 supra. 
proceedings on absent class members shall turn solely on the nature of the relief requested. Johnson will inevitably have an adverse impact on (b) (2) class actions, and this impact is not required by either rule 23 or the constitutional guarantee of due process; one distressing aspect of Johnson is that these basic issues did not even have to be addressed by the Fifth Circuit in this case. Such a flat, nondiscretionary notice requirement is an unfortunate rule of procedural law which should not be adopted or extended by other federal courts. 